\title{
Recruitment of juvenile corals onto coral tables preyed upon by Acanthaster planci
}

\author{
Carden C. Wallace*, Annemarie Watt \& Gordon D. Bull \\ Marine Biology Department, James Cook University, Townsville 4811, Queensland, Australia
}

\begin{abstract}
Corals of 3 table-forming species of the genus Acropora, whose tissues had been removed by the seastar Acanthaster planci (L.) during 2 mo prior to a major annual coral-spawning season, acted as substrata onto which juvenile corals settled. Juvenile corals were detected microscopically in the laboratory on samples taken from tables $10 \mathrm{wk}$ after spawning time (mean diameter of juveniles $1.3 \mathrm{~mm}$; density 3.5 per $100 \mathrm{~cm}^{2}$ ). Previously it had been thought that a delay of at least 1 yr was necessary before corals would settle after predation by $A$. planci. The same tables were sampled again after the next coral-spawning season (1 yr later). Despite the presence of algae and other colonizing organisms, new corals had settled at a density of 2.8 per $100 \mathrm{~cm}^{2}$. About $34 \%$ of the previous year's juveniles had survived, and mean diameter of these was now $7.24 \mathrm{~mm}$. When tables were searched closely in the field, surviving juveniles and some new recruits (with diameters down to $2.00 \mathrm{~mm}$ ) could be detected. These results indicate that apparent delay in settlement after predation by $A$. planci can be due to the small size of newly settled corals, which can only be seen by careful inspection of the substratum during the first year after settlement, and which do not achieve 3-dimensional structure until some time later. A. planci was still present at the site when these observations were made. Thus re-establishment of the coral community on this reef had begun during the time that the adult community was being preyed upon.
\end{abstract}

\section{INTRODUCTION}

The predatory seastar Acanthaster planci (Linnaeus) removes the tissues of its coral prey, leaving the skeleton bare. When seastars are numerous, few corals escape predation (e.g. Chesher 1969, Pearson \& Endean 1969, Branham 1973, Endean 1973, review in Potts 1981) and afterwards new scleractinian corals do not become evident for some years (Endean 1973, 1974, 1976, Endean \& Stablum 1973b, Randall 1973, Birkeland unpubl. report 1979). Although no detailed studies exist for recruitment of coral larvae immediately after such an event, several generalizations based on field observations have been made, in particular: (a) there is a lag period of at least a year before coral larvae can settle, some sort of preconditioning being required before the substratum is suitable (Pearson 1981 [review], Colgan 1982); (b) rapid coverage of coral skeletons by algal growth or soft corals creates a barrier to settlement of coral larvae (Endean 1973, 1976, Potts 1981); (c) even if larvae do settle on skele-

\footnotetext{
- Present address: Bureau of Flora and Fauna, P. O. Box 1383. Canberra 2601, Australia
}

(c) Inter-Research/Printed in F. R. Germany tons of corals killed by Acanthaster planci, subsequent growth of algae or soft corals, or other factors such as break-up and movement of the skeletal material, cause early mortality (Endean 1973, 1976)

Similar delays have been seen before settlement of corals onto artificial substrata (Schuhmacher 1974, 1977. Loya 1976) and to new surfaces provided by volcanic material (Grigg \& Maragos 1974). Recent findings on recruitment to experimentally placed settlement plates, examined microscopically after a few months, offer some explanations for these patterns. Apparent delay in settlement is likely to be an observational error, due to the small size of juvenile corals, and a time lag due to the seasonal nature of availability of coral larvae. Juveniles of most species of corals are recognised only with difficulty before 1 yr old (Wallace 1983, 1985a, Babcock 1985, Harriott 1985) and their censusing requires close scrutiny of the substratum (e.g. Bak \& Engel 1979, Sakai \& Yamazato 1984). On the Great Barrier Reef, the greatest number and variety of larvae are available in summer, after the major coral-spawning season (Harrison et al. 1984, Wallace 1985b, Willis et al. 1985, Babcock et al. 1986). Although heavy algal cover may affect survival of 
juvenile corals (Birkeland 1977), algae have been shown not to inhibit settlement (Sammarco 1980, Sammarco \& Carleton 1982).

Availability of coral larvae has been noted as a further factor potentially limiting recruitment after predation by Acanthaster planci, usually in the context of reduced local coral populations (Randall 1973, Endean \& Stablum 1973b, Pearson 1981). These authors assumed dependence on localized recruitment, since most corals were thought to release brooded larvae. The possibility that coral populations may derive recruits from non-localized sources of larvae is indicated by recent findings that the majority of corals are broadcast spawners, whose offspring do not settle until 4 to 17 d after release (Kojis \& Quinn 1981, Harrison et al. 1984, Schlesinger \& Loya 1985, Babcock \& Heyward in press).

Such findings suggested a reappraisal of settlement and survival of juvenile corals after predation by Acanthaster planci. An opportunity was presented by a population increase of the seastar, and subsequent demise of coral populations, on a reef where experimental studies of coral recruitment were underway (Wallace \& Bull 1982, Wallace 1985a, 1985b).

The study reef (Big Broadhurst Reef) was not damaged by Acanthaster planci during the population outbreaks in the late 1960s (Pearson \& Endean 1969 as 'Shinbun Reef'; Endean \& Stablum 1973a as 'Lynch Reef'), although its close neighbour, Broadhurst Reef, suffered a heavy infestation (Pearson \& Endean 1969, Endean \& Stablum 1973a). In the next outbreak (1979 to present, see Anonymous 1985), of the 2 reefs only Big Broadhurst Reef has thus far been damaged. In mid 1981, large $(>40 \mathrm{~cm})$ and small $(6$ to $22 \mathrm{~cm})$ individuals of the seastar were present at densities of 1 and up to
8 per $50 \mathrm{~m}^{2}$ respectively (small seastar information from T. Walker pers. comm.). By October 1984, large seastars were present at an estimated density of 5 per $50 \mathrm{~m}^{2}$. During 1981 and 1982, individual seastars were killing small coral colonies and portions of larger colonies (Wallace 1985c). By late 1983, whole large coral tables were being killed, and their skeletons stood out clearly amongst the live or algae-covered corals of the reef front (Fig. 1). About $60 \%$ of the previously present coral cover remained alive, and colonies of many species contained ripe gonads and spawned during the mass spawning event during the week following the November full moon (Wallace 1985c, Willis et al. 1985 , Babcock et al. 1986). One yr later (October 1984), only an estimated 10 to $20 \%$ of the coral cover remained alive, as patches of flourishing corals on the reef top.

We followed recruitment to tables denuded in late 1983, asking: (a) did juvenile corals settle during the first season after predation, when tables had been dead for less than 2 mo? (b) did newly settled corals survive beyond 1 yr? (c) did new corals settle after the following reproductive season, 1 yr later, when tables already had 1 yr's growth of benthic organisms and when few live corals remained as a source of local recruitment?

\section{METHODS}

Study sites. Coral tables used in this study were located around the edges of 2 adjacent surge channels on the SW front of Big Broadhurst Reef off the Queensland coast (see Wallace 1985b for map). These channels were flanked by 2 buttresses where recruitment of juvenile corals to settlement plates has been

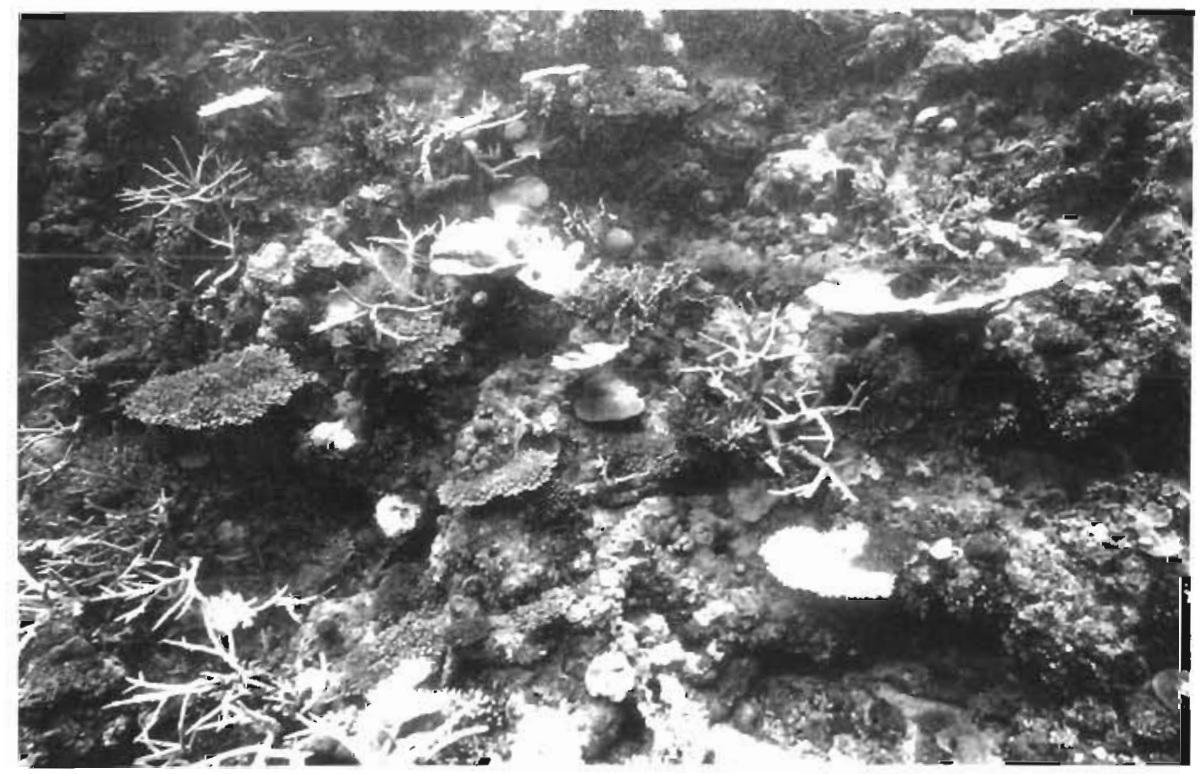

Fig. 1 Reef front near study sites in Oct 1983, showing white skeletons of freshly killed Acropora colonies interspersed amongst darker living and dead colonies 
studied for 2 and 5 yr, respectively (by 1985). During a visit to these sites to study spawning of corals in late November 1983, we noted the positions of 11 large tables, freshly killed since a visit in early October. The tables were from 3 species, Acropora hyacinthus Dana 1846, A. cytherea Dana 1846 and A. clathrata Brook 1891 (see Wallace 1978). All were at 3 to $5 \mathrm{~m}$ depth on the slopes and base of the reef buttresses.

Study of recruitment immediately after predation. To determine whether coral larvae from the 1983 spawning event settled on these tables, we took a sample from each table (total 11 samples) in February 1984, $10 \mathrm{wk}$ after the time of major offshore spawning (Table 1). This was long enough for recruits to develop

Table 1. Sequence of relevant events and sampling times

\begin{tabular}{|ll|}
\hline \multicolumn{1}{|c|}{ Date } & \multicolumn{1}{c|}{ Event } \\
\hline Oct-Nov 1983 & Tables killed \\
23-26 Nov 1983 & $\begin{array}{l}\text { Mass offshore coral spawning event } \\
\text { 7 Feb 1984 }\end{array}$ \\
Tables sampled for lab. study \\
11-14 Nov 1984 & Juveniles photographed in situ \\
12 Feb 1985 & Tables sampled for lab. study; \\
& juveniles measured in field \\
\hline
\end{tabular}

a recognizable skeleton. Samples with top and bottom surface areas of 150 to $200 \mathrm{~cm}^{2}$ were removed carefully with a hacksaw. They were fixed in $10 \%$ formalin for $1 \mathrm{wk}$ and then air-dried. They were then marked with 10 squares, each of $10 \mathrm{~cm}^{2}$, on each of the upper and lower surfaces, giving a total sampling surface of $200 \mathrm{~cm}^{2}$ per sample. They were searched twice (by 2 different examiners) under a binocular microscope lit by a fibre optic light source. All corals found within the squares were marked, photographed, measured for diameter (see Wallace 1985a), and identified to family.

Coral tables provide a natural, irregular surface of short branchlets interspersed with depressions, so that alternately exposed and protected positions occur in roughly equal proportions over the surface. Juvenile corals were recorded as occupying 'exposed' or 'protected' sites. Because of the anastomosing branching patterns, some depressions contained holes connecting to the other side of the table.

Study of recruitment during second year after predation. To determine whether coral larvae from the 1984 coral-spawning event settled on the tables, we took samples again in February 1985, following the same procedures and examining the samples as before. During this and the previous sampling time, settlement of larvae onto settlement plates was being monitored at 10 sites on the 2 nearby buttresses (Wallace 1985b, Wallace \& Watt unpubl. data).

Survival. Survival of the first year's recruits was examined (a) by recognizing older juveniles from size classes of juveniles on the second year's samples, and (b) by examination of the tables in situ. Tables were examined in early October 1984, when they had been dead for $12 \mathrm{mo}$, to see whether recruits had become visible. In February 1985, visible recruits were measured for maximal and median diameter.

\section{RESULTS}

\section{Settlement immediately after predation}

On the first samples, taken 4 mo after predation (Table 1), 78 juvenile corals were found $(7.00, \mathrm{SE} \pm$ 2.02 , per $200 \mathrm{~cm}^{2}$ ). Significantly more (53) were on lower surfaces than on upper surfaces (25) (chi-square test, $p<0.05$ ). Those on lower surfaces were distributed randomly between exposed and protected positions, but those on upper surfaces were situated preferentially in protected positions. Most recruits (68.8\%) were from the family Acroporidae, with the remainder from Pocilloporidae $(18.2 \%)$, Poritidae $(1.3 \%)$ and other families (10.4\%) (Fig. 2 ); $1.3 \%$ were unidentifiable because of extremely small size or damaged condition. Diameters ranged from 0.50 to $3.80 \mathrm{~mm}$, with a mean of $1.34 \mathrm{~mm} \mathrm{SE} \pm 0.07$ (Fig. 3).

\section{Settlement during second recruitment season}

On the second set of 11 samples, taken 1 yr later in February 1985,88 corals were found $\left(8.1\right.$ per $200 \mathrm{~cm}^{2}$, $\mathrm{SE} \pm 2.1$ ), and 2 size categories could be detected (Fig. 3). One category, with a range of diameters from 0.60 to $2.50 \mathrm{~mm}$ and a mean of $1.33 \mathrm{~mm} \mathrm{SE} \pm 0.05$, consisted of 61 new recruits from the 1984-5 recruitment season. The other, with a range of 4.00 to $16.00 \mathrm{~mm}$ and a mean diameter of $7.24 \mathrm{~mm} \mathrm{SE} \pm 0.07$, consisted of surviving juveniles from the 1983-4 season, plus any which might have settled during the intervening year. The 61 new recruits showed no significant difference in numbers settled on upper and lower surfaces (chi-square test, $\mathrm{p}>0.05$ ).

\section{Survival of recruits and visibility in the field}

Survival of recruits, based on the density of large juveniles on the second set of samples, was approximately $34 \%$. Of 27 survivors on 11 samples taken after $16 \mathrm{mo}, 16$ were on the upper surfaces of tables. Nine of the 11 survivors on lower surfaces were from the ahermatypic genera Tubastrea and Dendrophyllia, and the other 2 were hermatypic corals. 

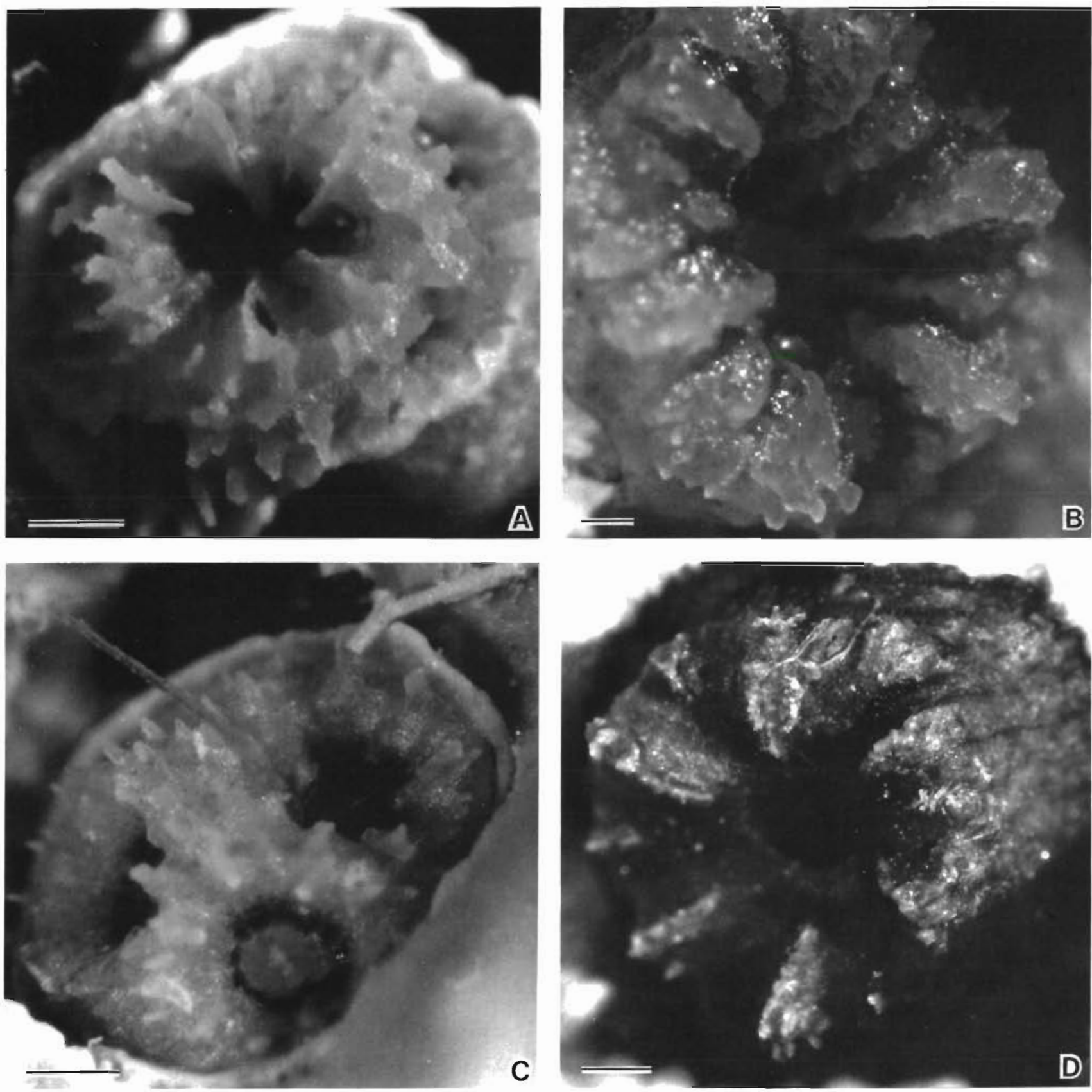

Fig. 2. Ten-week-old coral recruits from coral tables sampled in Feb 1984. (A) Acroporidae; (B) Faviidae ('other'); (C) Pocilloporidae; (D) Dendrophyllidae ('other'). Scale bars: $0.200 \mathrm{~mm}$

Small corals could be detected in the field on close examination of the tables in October 1984 (Fig. 4). By that time, and in the following February when diameters were measured in the field, growth was encrusting. Only 1 of the tables had broken from its stalk by February 1985, and it had fallen about $0.5 \mathrm{~m}$ without overturning. Field examination of tables in February 1985 yielded 47 juvenile corals which could be measured. (Others, because of their position within crevices or on undersurfaces, were not accessible.) The mean diameter of recruits measured in the field was
$8.9 \mathrm{~mm}(\mathrm{SE} \pm 0.64)$. Five of the recruits measured were under $4 \mathrm{~mm}$ diameter, and the smallest was $2 \mathrm{~mm}$ : these were thus likely to be recruits from the November 1984 spawning season.

\section{DISCUSSION}

Since recruitment occurred during the first 4 mo after predation, we conclude that coral tables freshly killed by Acanthaster planci act as substrata for settle- 


\section{A: Samples taken February 1984}

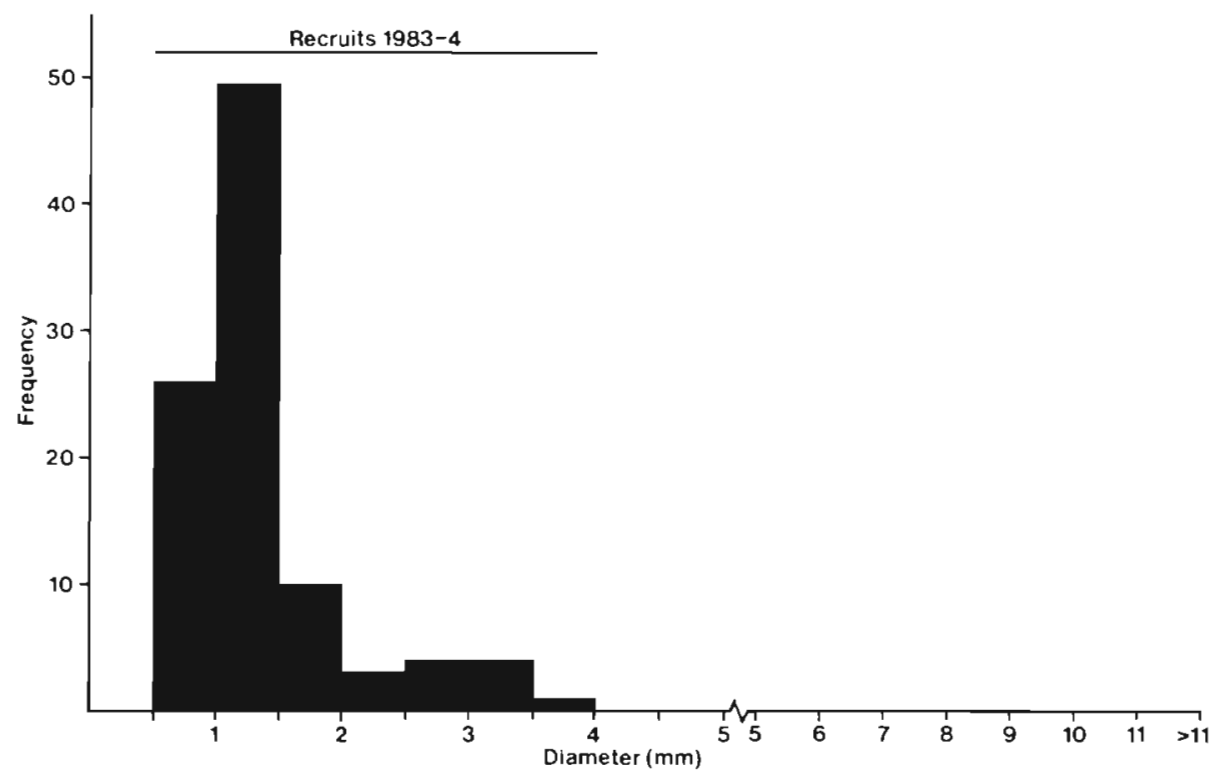

B : Samples taken February 1985

Fig. 3. Size distribution of juvenile corals found on samples from 11 Acropora tables. Total area sampled $2200 \mathrm{~cm}^{2}$. (A) Feb 1984, 4 mo after predation; (B) Feb 1985, 16 mo after predation

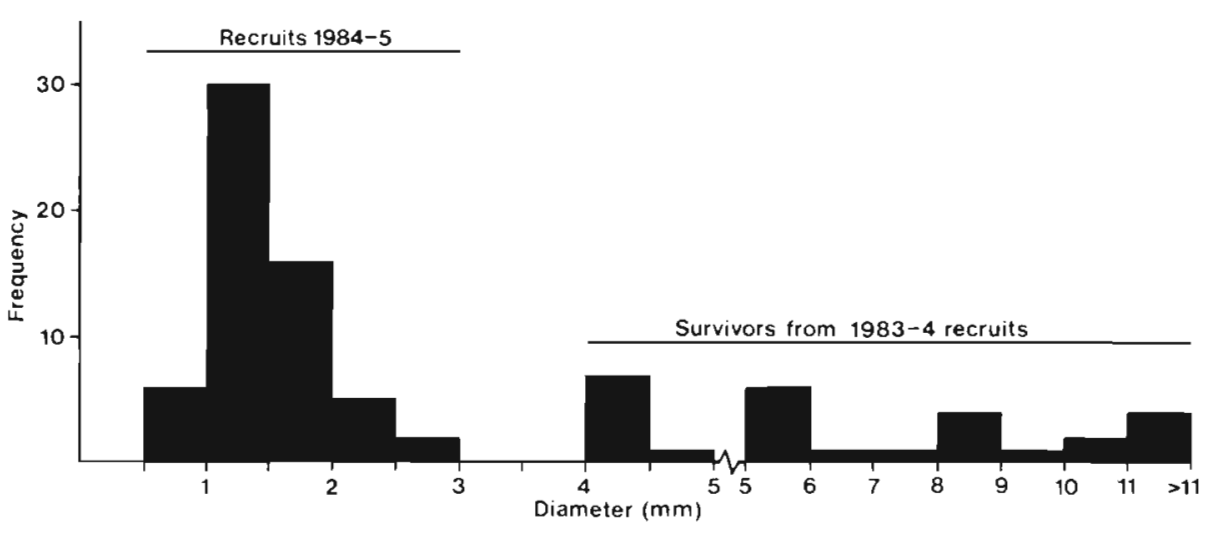

Approximately $34 \%$ of the settled juveniles survived beyond $1 \mathrm{yr}$. Thus we conclude that death of early colonizing larvae due to overgrowth by algae and other organisms is not responsible for the apparent lack of new corals after predation by Acanthaster planci. Grazing animals may have removed newly settled juveniles from the upper surfaces of tables, as few juveniles were found in exposed positions on upper surfaces. With 1 exception, coral tables did not break up and fall during the 16 mo of our observations. Breakage and redistribution of coral tables apparently is very dependent on cyclonic influences in the locality (Wallace 1985c). Such influences did not occur during the study. Should the tables have been overturned, at least in the first few months after settlement (the most likely time of the year for cyclonic weather on the Great Barrier Reef), a different set of juveniles might have survived, namely those on undersurfaces rather than upper surfaces. period, so recruits will become obvious 1 yr after this period (Harriott 1985, Wallace 1985a). 

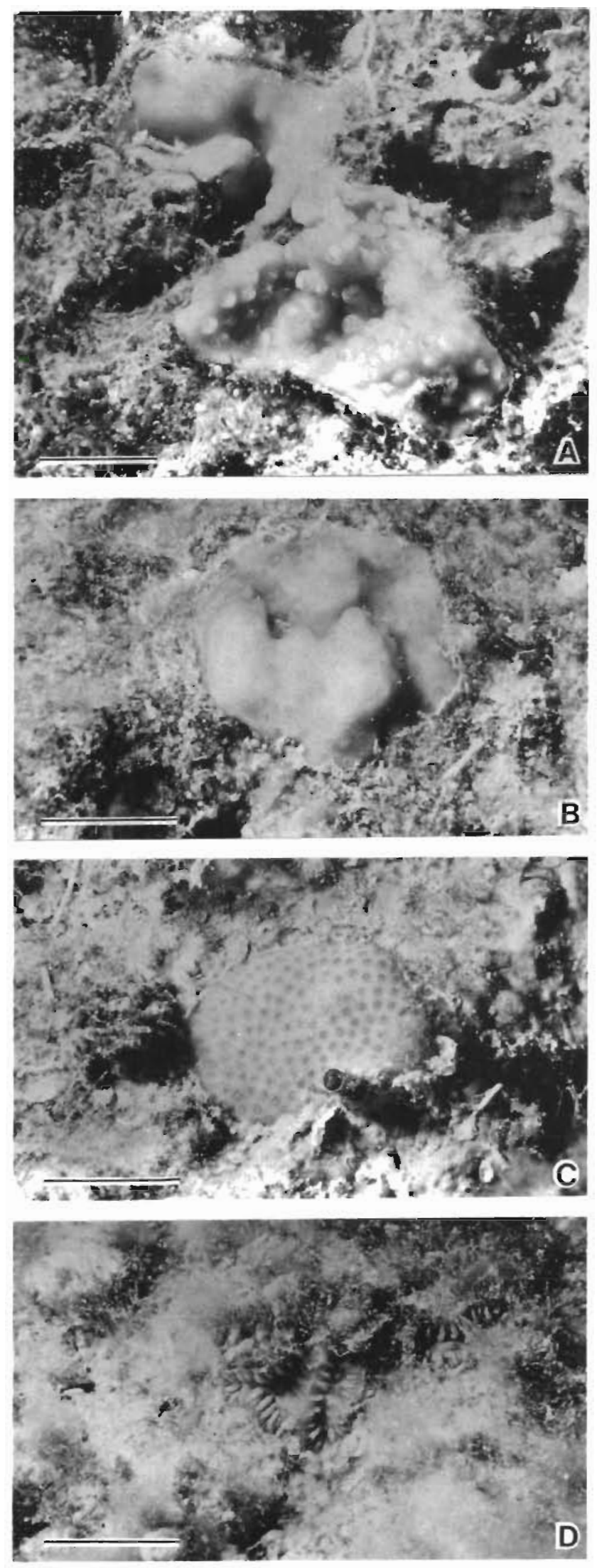

\section{Recruitment rates in first versus second year}

Although recruitment occurred in the second year, when tables had a considerable covering of algae and benthic invertebrates, including other corais, the rate of recruitment was less than that in the first year. Such a reduction might be attributed to exclusion by competition for space from other organisms. This conclusion, however, relies on an assumption of equal availability of larvae in the 2 yr. Before making this assumption, we examined our own data on recruitment to settlement plates placed on an adjacent reef buttress. We have been monitoring recruitment to experimentally placed settlement plates since 1980/81 (Wallace \& Bull 1982, Wallace 1985a, b, Wallace \& Watt unpubl. data). In 1983/84, mean recruitment to a set of 4 sites arranged down the reef front from 0 to $12 \mathrm{~m}$ was 20.1 (SE \pm 3.1 ) per $200 \mathrm{~cm}^{2}$. Recruitment in that year to a reef shoulder site, which was the most similar location in depth to that of the tables, was 7.2 (SE \pm 3.7 ) per $200 \mathrm{~cm}^{2}$ (Wallace $1985 \mathrm{~b}$ ). In the following year, both mean recruitment to all sites and that to the reef shoulder were significantly less (16.80 SE \pm 1.77 and 3.13 $\mathrm{SE} \pm 0.69$ respectively). The lowered recruitment rate on the Acropora tables preyed upon by Acanthaster planci, from 7.00 per $200 \mathrm{~cm}^{2}$ in $1983 / 84$ to 5.6 per $200 \mathrm{~cm}^{2}$ in $1984 / 85$ is within the range of variability expected because of lowered availability of larvae in the second year. Thus there is no basis for a hypothesis of competitive exclusion in the second year.

\section{Pattern of predation and coral recruitment}

Invasion of a reef by Acanthaster planci and subsequent re-establishment of the coral community usually are considered as 2 separate events: $A$. planci appears in large numbers, kills most of the corals, and disappears; after this, recruitment of new corals and regrowth of partially-dead corals begins (Colgan 1982, Endean 1976, Pearson 1974, 1981). Our results indicate a more integrated process. Small, then increasingly larger patches of corals were killed by the seastar over a period of more than $4 \mathrm{yr}$. By the time the corals of the reef front were killed by $A$. planci, patches potentially carried up to 4 year-classes of juvenile corals. Our sampling demonstrates that at least 2 year-classes of young corals existed on the reef before the $A$. planci population had abated in the area. Thus the recolonization of this reef had commenced well ahead of the demise of the previously existing populations.

Fig. 4. Juvenile corals estimated to be 10 mo old, photographed in situ 12 mo after predation of coral tables by Acanthaster planci. (A) Acropora (2 colonies); (B) Acropora;

(C) Porites; (D) cf. Leptastrea. Scale bars: $10 \mathrm{~mm}$ 


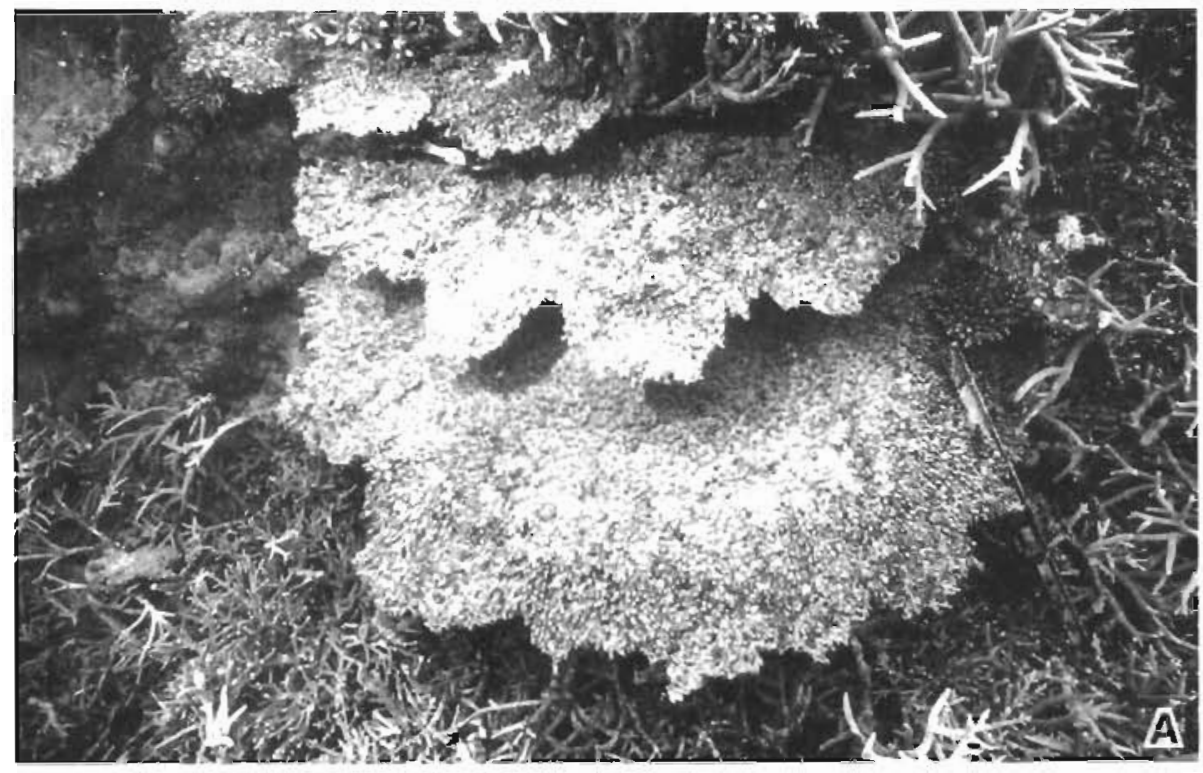

Fig. 5. Dead Acropora tables photographed (A) in Feb 1984, 4 mo after predation by Acanthaster planci and (B) in Feb 1985. Samples taken at both times had new recruits and (B) also had surviving juveniles, approximately 15 mo old. Even on $(B)$ these were only obvious on close examination of the surface, because of their small size and encrusting nature

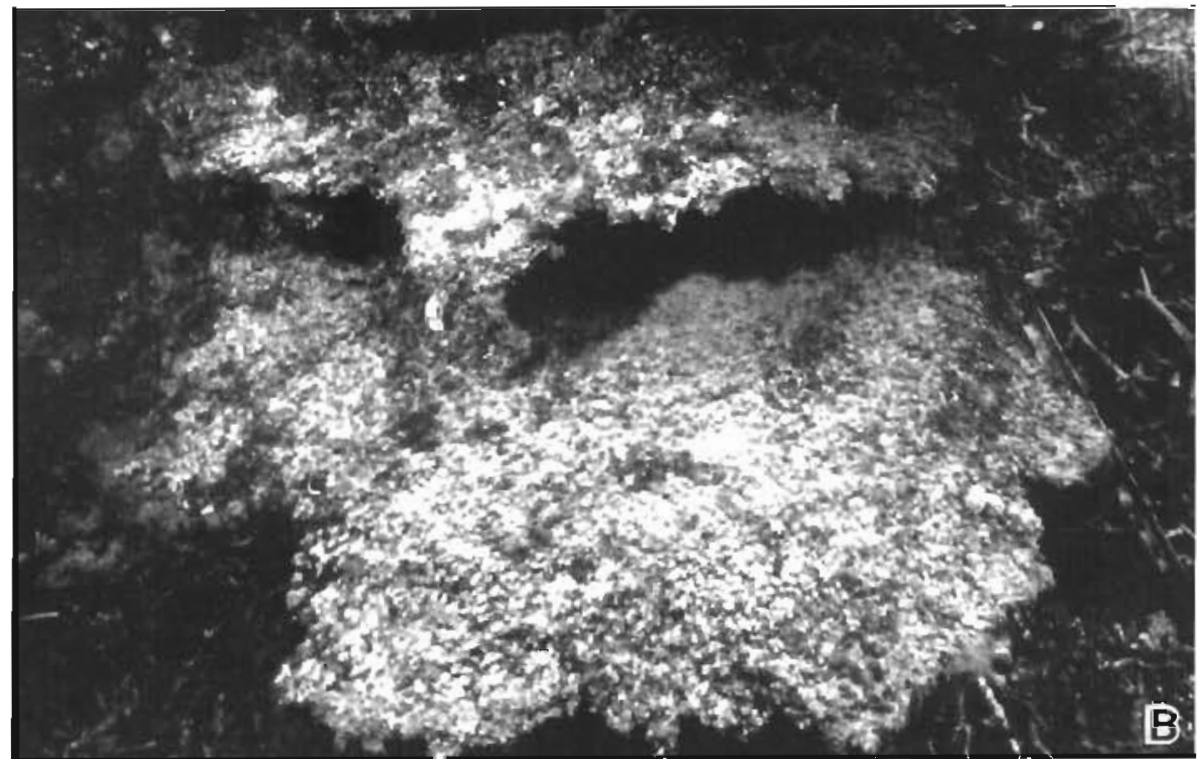

Acknowledgements. This study was funded by the Marne Sciences and Technology Grants Scheme. We gratefully acknowledge the assistance of $\mathrm{J}$. Barnett with underwater photography, of G. Moore, G. Bridle, T. Roe, P. Speare and C. Bone with diving, G. Kelly in the laboratory and R Smith with illustration. For their comments on the manuscript we thank R. C. Babcock, J. H. Connell, V. J. Harnott, R A. Kenchington, G. R. Russ and T. Walker

\section{LITERATURE CITED}

Anonymous (1985). Report of the Crown of Thorns Advisory Committee. 11 January 1985. Great Barner Reef Manne Park Authority, Townsville, p. 1-19

Babcock, R. C. (1985). Growth and mortality in juvenule corals (Goniastrea, Platygyra and Acropora): the first year In Gabrie, G., Salvat, B. (ed.) Proc. 5th Int. Coral Reef Congress (4). Antenne Museum-Ephe, Tahitı, p. 355-360
Babcock, R. C, Bull, G. D., Harnson, P. L., Heywood, A. J., Olıver, J K., Wallace, C C, Willss, B. L. (1986). Synchronous spawnings of 105 scleractinian coral species on the Great Barner Reef. Mar. Bıol. 90: 379-394

Babcock, R. C., Heyward, A. (In press). Larval development of certain gamete-spawning scleractinian coral species. Coral Reefs

Bak, R P. M., Engel, M. S. (1979). Distrbution, abundance and survival of juvenule hermatypic corals and the importance of life history strategies in the parent coral community. Mar. Biol 54: 341-352

Branham, J. M. (1973). The crown of thorns on coral reefs. Bioscience 23: 219-226

Burkeland, C. (1977) The importance of rate of biomass accumulation in early successional stages of benthic communites to the survival of coral recruits. In: Taylor. D L (ed.) Proc. 3rd Int. Coral Reef Symp. University of Miamı, Miami, p. 15-21

Chesher, R. H. (1969). Destruction of Pacific coral reef communities. In: Jones, O. A., Endean, R. (ed.) Brology and 
geology of coral reefs. Vol, 3. Academic Press, London, p. 215-254

Colgan, M. (1982). Succession and recovery of a coral reef after predation by Acanthaster planci. In: Gomez, E. D., Birkeland, C. E., Buddemeier, R. W., Johannes, R. E., Marsh, J. A., Jr., Tsuda, R. T (ed.) Proc. 4 th Int. Coral Reef Symp. (2). University of Philippines, Manila, p. 333-338

Endean, R. (1973). Population explosions of Acanthaster planci and associated destruction of hermatypic corals in the Indo-West Pacific region. In: Jones, O. A., Endean, R. (ed.) Biology and geology of coral reefs. Vol. 2. Academic Press, London, p. 389-438

Endean, R. (1974). Acanthaster planci on the Great Barrier Reef. In: Cameron, A. M., Campbell, B. M., Cribb, A. B. Endean, R., Jell, J. S., Jones, O. A., Mather, P., Talbot, F. $\mathrm{H}$. (ed.) Proc. 2nd Int. Coral Reef Symposium (1). Great Barrier Reef Commitee, Brisbane, p. 563-576

Endean, R. (1976). Destruction and recovery of coral reef communities. In: Jones, O. A., Endean, R. (ed.) Biology and geology of coral reefs. Vol. 3. Academic Press, London, p. 215-254

Endean, R., Stablum, W. (1973a). A study of some aspects of the crown-of-thorns starfish (Acanthaster planci) infestations of Australia's Great Barrier Reef. Atoll Res. Bull. 167 $1-62$

Endean, R., Stablum, W. (1973b). The apparent extent of recovery of reefs of Australia's Great Barrier Reef devastated by the crown-of-thorns starfish (Acanthaster planci). Atoll Res. Bull. 168: 1-26

Grigg, R., Maragos, J. (1974). Recolonization of hermatypic corals on subnerged lava flows in Hawaii. Ecology 55: $387-395$

Harriott, V. J. (1985). Recruitment patterns of scleractinian corals at Lizard Island, Great Barrier Reef. In: Gabrie, G., Salvat, B. (ed.) Proc. 5th Int. Coral Reef Congress (4). Antenne Museum-Ephe, Tahiti, p. 367-372

Harrison, P. L., Babcock, R. C., Bull, G. D., Oliver, J. K., Wallace, C. C., Willis, B. L. (1984). Mass spawning of tropical reef corals. Science 223: 1186-1189

Kojis, B. L., Quinn, N. J. (1981). Aspects of sexual reproduction and larval development in the shallow water hermatypic coral Goniastrea australiensis (Edwards and Haime, 1857). Bull. mar. Sci. 31. 558-573

Loya, Y. (1976). Settlement, mortality and recruitment of a Red Sea scleractinian coral population. In: Mackie, G. O. (ed.) Coelenterate ecology and behavior. Plenum Press, New York, p. 89-100

Pearson, R. G. (1974). Recolonization by hermatypic corals of reefs damaged by Acanthaster In: Cameron, A. M., Campbell, B. M., Cribb, A. B., Endean, R., Jell, J. S., Jones, O. A., Mather, P., Talbot, F. H. (ed.) Proc. 2nd Int. Coral Reef Symp. (2). Great Barrier Reef Committee, Brisbane, p. 207-215

Pearson, R. G. (1981). Recovery and recolonization of coral reefs. Mar Ecol. Prog. Ser. 4: 105-122

Pearson, R. G., Endean, R. (1969). A preliminary study of the coral predator Acanthaster planci (L.) (Asteroidea) on the Great Barrier Reef. Fisheries Notes, Queensland Dept. Harbours and Marine 3: 27-55

Potts, D. C. (1981). Crown of thorns starfish - man-induced pest or natural phenomenon? In: Kitching, R. L., Jones, R. E. (ed.) The ecology of pests. Some Australian case histories. CSIRO, Melbourne, p. 55-86
Randall, R. H. (1973). Distribution of corals after Acanthaster planci (L.) infestation of Tanguissam Point, Guam. Micronesica 3: 213-222

Sakai, K., Yamazato, K. (1984). Coral recruitment to artificially denuded natural substrates on an Okinawan reef flat. Galaxea 3: 57-69

Sammarco, P. W. (1980). Diadema antillarum and its relationship to coral spat mortality: grazing, competition, and biological disturbance. J. exp. mar. Biol Ecol. 45: 245-272

Sammarco, P. W. (1983). Coral recruitment across the Central Great Barrier Reef: a preliminary report. In: Baker, J. T. Carter, R., Sammarco, P. W., Stark, K. (ed.) Proc. Great Barrier Reef Conf. James Cook University Press, Townsville, p. 245-258

Sammarco, P. W., Carleton, J. H. (1982). Damselfish territoriality and coral community structure: reduced grazing, coral recruitment and effects on coral spat. In: Gomez, E D., Birkeland, C. E., Buddemeier, R. W., Johannes, R. E., Marsh, J. A. Jr., Tsuda, R. (ed.) Proc. 4th Int. Coral Reef Symp. (2). University of Philippines, Manila, p. 526-535

Schlesinger, Y., Loya, Y. (1985). Coral community reproductive patterns: Red Sea versus the Great Barrier Reef. Science 228: 1333-1335

Schuhmacher, $\mathrm{H}$. (1974). On the conditions accompanying the first settlement of corals on artificial reefs with special reference to the influence of grazing sea urchins (Eilat, Red Sea). In: Cameron, A. M., Campbell, B. M., Cribb, A. B., Endean, R., Jell, J. S., Jones, O. A., Mather, P., Talbot, F. H. (ed.) Proc. 2nd Int. Coral Reef Symp. (1). Great Barrier Reef Committee, Brisbane, p. 257-267

Schuhmacher, H. (1977). Initial phases in reef development, studied at artificial reef types off Eilat, Red Sea. Helgoländer Meeresunters. 30: 400-411

Wallace, C. C. (1978). The coral genus Acropora (Scleractinia: Astrocoeniina: Acroporidae in the central and southern Great Barrier Reef Province. Mem Qd Mus. 18: 273-319 + Pls 43-103

Wallace, C. C. (1983). Visible and invisible coral recruitment. In: Baker, J. T., Carter, R., Sammarco, P. W., Stark, K. (ed.) Proc. Great Barrier Reef Conf. James Cook University Press, Townsville, p. 259-261

Wallace, C. C. (1985a). Seasonal peaks and annual fluctuations in recruitment of juvenile scleractinian corals. Mar. Ecol. Prog. Ser. 21: 289-298

Wallace, C. C. (1985b). Four years of juvenile coral recruitment to five reef front sites. In: Gabrie, G., Salvat, B. (ed.) Proc. 5th Int. Coral Reef Congress (4). Antenne MuseumEphe, Tahiti, p. 385-390

Wallace, C. C. (1985c). Reproduction, recruitment and fragmentation in nine sympatric species of the coral genus Acropora. Mar. Biol. 88: 217-233

Wallace, C. C., Bull, G. D. (1982). Patterns of juvenile cora] recruitment on a reef front during a spring-summer spawning period. In: Gomez, E. D., Birkeland, C. E., Buddemeier, R. W., Johannes, R. E., Marsh, J. A. Jr., Tsuda, R. I (ed.) Proc. 4th Int. Coral Reef Symp. (2). University of Philippines, Manila, p. 345-350

Willis, B. L., Babcock, R. C., Harrison, P. L., Oliver, J. K., Wallace, C. C. (1985). Patterns in the mass spawning of corals on the Great Barrier Reef from 1981 to 1984. In: Gabrie, G., Salvat, B. (ed.) Proc. 5th Int. Coral Reef Congress (4). Antenne Museum-Ephe, Tahiti, p. 343-348 